\title{
Effect of Different Organic Manures on Plant Growth and Establishment of Apple Guava
}

\author{
Shashi Kant Ekka* and S. S. Saravanan \\ Department of Horticulture, Sam Higginbottom University of Agriculture Technology and \\ Science, Prayagraj (U.P.), India \\ *Corresponding author
}

A B S T R A C T

Keywords

Guava, Organic

manures,

Vegetative growth

Article Info

Accepted:

07 October 2020

Available Online:

10 November 2020
The experiment was laid out in Randomized Block Design (RBD) with three replication. Revealed that the application $\mathrm{T}_{7}$ Farm Yard Manure $5 \mathrm{~kg}+$ Neem Cake $200 \mathrm{gm}$ significantly influence the vegetative growth viz, plant height $(142.74 \mathrm{~cm})$, number of leaves plant ${ }^{-1}(121.57)$, number of branches plant ${ }^{-1}(10.73)$, stem length $(\mathrm{cm})(18.24)$, stem girth $(\mathrm{cm})(3.50)$, plant spread $(\mathrm{cm})$ (East - West) $(17.89 \mathrm{~cm})$, plant spread $(\mathrm{cm})$ (North South) (18.50), leaf area $\left(29.03 \mathrm{~cm}^{2}\right)$, leaf area index (LAI) $\left(1.45 \mathrm{~m}^{2}\right)$, chlorophyll ( $\mathrm{a}$ and $\mathrm{b})$ content $(\mathrm{mg} / \mathrm{g})(3.24$ and 2.68).

\section{Introduction}

Guava (Psidium guajava L.) is one of the most important and commercially cultivated fruit crop belonging to the family Myrtaceae. It is one of the privileged fruits liked by the common masses and is aptly known as "apple of the tropics". Guava is said to have originated in Tropical America (Hayes 1953) and it was introduced in India by the Portuguese during 17th century. Guava is classified under genus Psidium, which encompasses 150 species but only Psidium guajava has been exploited commercially in terms of commercial success. India is the leading producer of guava in the world and it shares about $45 \%$ of total production of guava in the world. The leading guava producing states in India are Madhya Pradesh, Uttar Pradesh, Maharashtra, Bihar, West Bengal, Gujarat and Karnataka (Anonymous, 2016). Apple guava: are a variety of guava having deep pink color inside instead of the typical white color and an apple red exterior skin. This fruit is sweet, and strongly flavoured with few seeds and is slightly depressed at both ends. The plants are vigorous, dome shaped and compact. These guavas are cultivated across the Allahabad, Uttar Pradesh region in the northern belt of 
India. Apple guava is cultivated today on almost 1000 hectares of land mainly under Kaushambi and Kaurihar -II districts of Allahabad ${ }^{]}$. The fruit is known for its medical properties such that during the winter season because it neutralizes disease symptoms.

\section{Materials and Methods}

The present investigation was carried out to study the "Effect of different organic manures on plant growth, and establishment of apple guava" was conducted under humid subtropical conditions of Uttar Pradesh, District Prayagraj during 2019-2020 at Horticulture Research Farm, Department of Horticulture, Sam Higgibottom University of Agriculture Technology and Science, Prayagraj (U.P.). The experiment was laid out in Randomized Block Design (RBD) with three replication. The experiment of thirteen treatment combination viz., $\mathrm{T}_{0} \quad \mathrm{RDF}$ (60:90:110 kg NPK ha $\left.{ }^{-1}\right), \mathrm{T}_{1}$ Farm Yard Manure 10kg, $\mathrm{T}_{2}$ Vermicompost $5 \mathrm{~kg}, \mathrm{~T}_{3}$ Poultry Manure $2.5 \mathrm{~kg}, \mathrm{~T}_{4}$ Goat Manure $5 \mathrm{~kg}$, $\mathrm{T}_{5}$ Leaf Mould 10kg, $\mathrm{T}_{6}$ Bone Meal $4 \mathrm{~kg}, \mathrm{~T}_{7}$ Farm Yard Manure 5kg + Neem Cake 200gm, $\mathrm{T}_{8}$ Vermicompost $-7.5 \mathrm{~kg}+$ Neem Cake $150 \mathrm{gm}, \mathrm{T}_{9}$ Poultry Manure-2.5kg $+100 \mathrm{gm}$ Neem Cake, $\mathrm{T}_{10}$ Goat Manure-2.5kg $+200 \mathrm{gm}$ Neem Cake, $\mathrm{T}_{11}$ Leaf Manure $7.5 \mathrm{~kg}+150 \mathrm{gm}$ Neem Cake and $\mathrm{T}_{12}$ Bone Meal $2.5 \mathrm{~kg}+$ 100gm Neem Cake were applied and data were analyzed statistically.

\section{Results and Discussion}

A cursory glance over the data depicted in Table 1 clearly shows that the treatments showed significant effect of organic manure on vegetative growth parameters. The highest plant height $(142.74 \mathrm{~cm})$ was recorded in $\mathrm{T}_{7}$ Farm Yard Manure 5kg+Neem Cake 200gm the minimum plant height $(110.97 \mathrm{~cm})$ was recorded in $T_{0}$ RDF (60:90:110 $\mathrm{kg}^{\text {NPK ha }}{ }^{-1}$ ). The maximum number of leaves plant ${ }^{-1}$
(121.57) was recorded in $\mathrm{T}_{7}$ Farm Yard Manure $5 \mathrm{~kg}+$ Neem Cake 200gm the minimum number of leaves plant $^{-1}$ (81.08) was recorded in $T_{0}$ RDF (60:90:110 kg NPK $\left.\mathrm{ha}^{-1}\right)$. The maximum number of branches plant $^{-1}$ (10.73) was recorded in $\mathrm{T}_{7}$ Farm Yard Manure $5 \mathrm{~kg}+$ Neem Cake 200gm the minimum number of branches plant ${ }^{-1}$ (7.55) was recorded in $\mathrm{T}_{0}$ RDF (60:90:110 kg NPK $\left.\mathrm{ha}^{-1}\right)$. The highest stem length (cm) (18.24) was recorded in $\mathrm{T}_{7}$ Farm Yard Manure $5 \mathrm{~kg}+\mathrm{Neem}$ Cake 200gm the minimum stem length $(\mathrm{cm})$ (14.84) was recorded in $\mathrm{T}_{0} \mathrm{RDF}$ (60:90:110 kg NPK ha-1). The highest stem girth $(\mathrm{cm})$ (3.50) was recorded in $\mathrm{T}_{7}$ Farm Yard Manure $5 \mathrm{~kg}+\mathrm{Neem}$ Cake 200gm the minimum stem girth $(\mathrm{cm})(2.93)$ was recorded in $\mathrm{T}_{0}$ RDF (60:90:110 $\mathrm{kg}$ NPK ha $\left.{ }^{-1}\right)$. The highest plant spread $(\mathrm{cm})$ (East - West) $(17.89 \mathrm{~cm})$ was recorded in $\mathrm{T}_{7}$ Farm Yard Manure $5 \mathrm{~kg}+$ Neem Cake 200gm the minimum plant spread $(\mathrm{cm})$ (East - West) (15.22) was recorded in $\mathrm{T}_{0}$ RDF (60:90:110 $\left.\mathrm{kg} \mathrm{NPK} \mathrm{ha}{ }^{-1}\right)$. The highest plant spread $(\mathrm{cm})$ (North - South) (18.50) was recorded in $\mathrm{T}_{7}$ Farm Yard Manure 5kg + Neem Cake 200gm the minimum plant spread $(\mathrm{cm})$ (North South) (15.66) was recorded in $\mathrm{T}_{0} \mathrm{RDF}$ (60:90:110 kg NPK ha $\left.{ }^{-1}\right)$. The maximum leaf area $(29.03 \mathrm{~cm} 2)$ was found in treatment with $\mathrm{T}_{7}$ Farm Yard Manure $5 \mathrm{~kg}+$ Neem Cake $200 \mathrm{gm}$ and the minimum leaf area $\left(18.61 \mathrm{~cm}^{2}\right)$ was recorded in $\mathrm{T}_{0} \mathrm{RDF}$ (60:90:110 kg NPK $\left.\mathrm{ha}^{-1}\right)$. The maximum leaf area index (LAI) $\left(1.45 \mathrm{~cm}^{2}\right)$ was found in treatment with $\mathrm{T}_{7}$ Farm Yard Manure 5kg+Neem Cake 200gm and the minimum leaf area index (LAI) $\left(1.10 \mathrm{~cm}^{2}\right)$ was recorded in $\mathrm{T}_{0} \mathrm{RDF}$ (60:90:110 $\mathrm{kg}$ NPK ha ${ }^{-1}$ ). The maximum chlorophyll (a and b) content (mg/g) (3.24 and 2.68) was found in treatment with $\mathrm{T}_{7}$ Farm Yard Manure $5 \mathrm{~kg}+$ Neem Cake 200gm and the minimum chlorophyll (a and b) content $(\mathrm{mg} / \mathrm{g})$ (3.08 and 2.21) was recorded in $\mathrm{T}_{0} \mathrm{RDF}$ (60:90:110 kg NPK ha ${ }^{-1}$ ). 
Table.1 Effect of different organic manures on vegetative growth of apple guava after transplantation (at 180 days).

\begin{tabular}{|c|c|c|c|c|c|c|c|c|c|c|c|c|}
\hline \multirow{2}{*}{$\begin{array}{l}\text { Treatment } \\
\text { notation }\end{array}$} & \multirow[t]{2}{*}{ Treatment combinations } & \multicolumn{11}{|c|}{ Vegetative growth } \\
\hline & & $\begin{array}{c}\text { Plant } \\
\text { height } \\
\text { (cm) }\end{array}$ & $\begin{array}{c}\text { Number of } \\
\text { leaves } \\
\text { plant }^{-1}\end{array}$ & $\begin{array}{c}\text { Number of } \\
\text { branches } \\
\text { plant }^{-1}\end{array}$ & $\begin{array}{c}\text { stem } \\
\text { length } \\
(\mathrm{cm})\end{array}$ & $\begin{array}{l}\text { stem } \\
\text { girth } \\
(\mathrm{cm})\end{array}$ & $\begin{array}{c}\text { plant } \\
\text { spread } \\
(\mathrm{cm}) \\
(\mathrm{E}-\mathrm{W})\end{array}$ & $\begin{array}{c}\text { plant } \\
\text { spread } \\
(\mathrm{cm}) \\
(\mathrm{N}-\mathrm{S})\end{array}$ & $\begin{array}{l}\text { leaf } \\
\text { area } \\
\left(\mathrm{cm}^{2}\right)\end{array}$ & $\begin{array}{l}\text { leaf } \\
\text { area } \\
\text { index } \\
\text { (LAI) }\end{array}$ & $\begin{array}{l}\text { chlorophyll } \\
\text { (a) }\end{array}$ & $\begin{array}{l}\text { chlorophyll } \\
\text { (a) }\end{array}$ \\
\hline $\mathbf{T}_{\mathbf{0}}$ & RDF (60:90:110 kg NPK ha ${ }^{-1}$ ) & 110.97 & 81.08 & 7.55 & 14.84 & 2.93 & 15.22 & 15.66 & 18.61 & 1.10 & 3.08 & 2.21 \\
\hline $\mathbf{T}_{1}$ & Farm Yard Manure 10kg & 128.54 & 99.89 & 8.43 & 16.36 & 3.31 & 15.97 & 17.83 & 23.59 & 1.50 & 3.14 & 2.74 \\
\hline $\mathbf{T}_{2}$ & Vermicompost $5 \mathrm{~kg}$ & 125.81 & 99.73 & 8.31 & 16.51 & 3.26 & 16.11 & 18.23 & 24.51 & 1.30 & 3.22 & 2.54 \\
\hline $\mathbf{T}_{3}$ & Poultry Manure $2.5 \mathrm{~kg}$ & 124.47 & 95.26 & 8.65 & 16.28 & 3.31 & 15.63 & 17.63 & 23.90 & 1.22 & 3.20 & 2.57 \\
\hline $\mathbf{T}_{4}$ & Goat Manure 5kg & 123.58 & 89.25 & 8.34 & 15.50 & 3.18 & 15.29 & 17.66 & 24.91 & 1.40 & 3.12 & 2.65 \\
\hline $\mathbf{T}_{5}$ & Leaf Mould 10kg & 118.51 & 101.60 & 8.22 & 15.40 & 3.32 & 16.37 & 17.81 & 25.55 & 1.26 & 3.16 & 2.50 \\
\hline $\mathbf{T}_{6}$ & Bone Meal 4kg & 115.48 & 96.00 & 8.28 & 16.54 & 3.46 & 16.40 & 18.33 & 27.29 & 1.43 & 3.20 & 2.58 \\
\hline $\mathbf{T}_{7}$ & $\begin{array}{l}\text { Farm Yard Manure } 5 \mathrm{~kg}+\text { Neem Cake } \\
\text { 200gm }\end{array}$ & 142.74 & 121.57 & 10.73 & 18.24 & 3.50 & 17.89 & 18.50 & 29.03 & 1.45 & 3.24 & 2.68 \\
\hline $\mathbf{T}_{8}$ & $\begin{array}{c}\text { Vermicompost }-7.5 \mathrm{~kg}+\text { Neem Cake } \\
150 \mathrm{gm}\end{array}$ & 138.38 & 115.89 & 9.63 & 17.54 & 3.50 & 17.34 & 16.39 & 27.86 & 1.30 & 3.19 & 2.64 \\
\hline $\mathbf{T}_{9}$ & $\begin{array}{c}\text { Poultry Manure- } 2.5 \mathrm{~kg}+100 \mathrm{gm} \text { Neem } \\
\text { Cake }\end{array}$ & 131.61 & 113.55 & 9.57 & 17.73 & 3.25 & 17.29 & 17.58 & 25.07 & 1.37 & 3.17 & 2.64 \\
\hline $\mathbf{T}_{10}$ & $\begin{array}{c}\text { Goat Manure-2.5kg+200gm Neem } \\
\text { Cake }\end{array}$ & 128.39 & 100.07 & 9.43 & 17.59 & 3.35 & 15.66 & 17.20 & 28.40 & 1.20 & 3.20 & 2.59 \\
\hline $\mathbf{T}_{11}$ & Leaf Manure $7.5 \mathrm{~kg}+150$ Neem Cake & 120.31 & 102.22 & 8.72 & 16.69 & 3.33 & 16.07 & 17.65 & 24.75 & 1.44 & 3.17 & 2.60 \\
\hline \multirow[t]{4}{*}{$\mathbf{T}_{12}$} & Bone Meal $2.5 \mathrm{~kg}+100$ Neem Cake & 118.41 & 98.52 & 8.51 & 17.51 & 3.34 & 16.92 & 17.98 & 23.47 & 1.29 & 3.18 & 2.65 \\
\hline & F-Test & $\mathbf{S}$ & $\mathbf{S}$ & $\mathrm{S}$ & $\mathbf{S}$ & $\mathrm{S}$ & $\mathrm{S}$ & $\mathrm{S}$ & $\mathbf{S}$ & $\mathbf{S}$ & $\mathbf{S}$ & $\mathbf{S}$ \\
\hline & C.D. at $0.5 \%$ & 0.981 & 2.795 & 0.541 & 0.803 & 0.247 & 1.530 & 0.967 & 4.867 & 0.265 & 0.393 & 0.287 \\
\hline & S.Ed ( \pm$)$ & 0.475 & 1.354 & 0.262 & 0.389 & 0.120 & 0.741 & 0.469 & 2.358 & 0.129 & 0.190 & 0.139 \\
\hline
\end{tabular}


The present findings corroborate with those of Athani et al., (2007), Naik and Babu (2007), Ram et al., (2007), Ram and Pathak (2007), Kumar et al., (2007), Dutta et al., (2009), Patel et al., (2009), Shukla et al., (2009), Dwivedi (2013) and Agnihotri et al., (2013) who found that vermicompost with FYM and inorganic fertilizers resulted increase in the vegetative growth.

In conclusion on the basis of the investigation it can be concluded that $\mathrm{T}_{7}$ Farm Yard Manure $5 \mathrm{~kg}+$ Neem Cake 200gm results as the best treatment combination in terms of vegetative growth parameters showed better results in Prayagraj agro climatic condition However, since this is based on one-year experiment, further trials may be needed to substantiate the results.

\section{References}

Agnihotri A, Tiwari R and Singh OP. 2013. Effect of crop regulators on growth, yield and quality of guava. Annals of Plant and Soil Research 15(1): 54-57

Athani et al., (2007 a) studied the influence of vermicompost on variation in growth parameters, fruit characters, quality and yield of 5-year-old guava cv. Sardar revealed that there was no significant difference among the treatments for growth parameters.

Athani S.I., A.I. Ustad, H.S. Prabhuraj, G.S.K. Swamy, P.B. Patil, Y.K. Kotikal (2005) Influence of vermi-compost on growth, fruit yield and quality of guava cv. Sardar, ISHS Acta Horticulturae 735: I International Guava Symposium https://doi.org/10.17660/ActaHortic.2007. 735.54.

Athani SI and Revanappa ATB. 2009. Influence of organic and inorganic fertilizers on growth, fruit characters, nutrient content and yield in guava. Journal of Eco biology 25(2): 131-137.
Athani SI, Prabhuraj HS, Ustad AI, Swamy GSK, Patil PB and Kotikal YK. 2007 b. Effect of organic and inorganic fertilizers on growth, leaf, major nutrient and chlorophyll content and yield of guava cv. Sardar. Acta Horticulture 735: 351-356.

Athani SI, Ustad AI, Prabhuraj HS, Swamy GSK, Patil PB and Kotikal YK. 2007a. Influence of vermi-compost on growth, fruit yield and quality of guava cv. Sardar. Acta Horticulturae 735: 381-385.

Dutta P, Moji SB and Das BS. 2009. Studies on the response of biofertilizer on growth and productivity of guava. Indian Journal of Horticulture 66(1): 39-42.

Dwivedi DH, Rubee L and Ram RB. 2010. Effect of biofertilizers and organic manures on yield and quality of guava cv. Red fleshed. The Scientific Temper 193: 193-198. Dwivedi, V. (2013. Effect of integrated nutrient management on yield, quality and economics of guava. Annals of Plant and Soil Research 15(2): 149-151.

Kumar P. and Rehalia AS. 2007. Standardization of micronutrient ranges in mango (Mangifera indica L.) by orchard survey. The Asian Journal of Horticulture 2(1): 218-221.

Shukla AK, Sarolia DK, Kumari B, Kaushik RA, Mahawere LN and Bairwa HL. 2009. Evaluation of substrate dynamics for integrated nutrient management under high density planting of guava cv. Sardar. Indian Journal of Horticulture 66(4): 461463.

Ram RA and Pathak RK. 2007 b. Integration of organic farming practices for sustainable production of guava. A case study. Acta Horticulturae (ISHS) 735: 357-363.

Ram RA, Bhringuvanshi SR, Garg N and Pathak RK 2007a. Studies on organic production of guava (Psidium guava L.) cv. Allahabad Safeda. Acta Horticulturae (ISHS) 735: 373-379.

\section{How to cite this article:}

Shashi Kant Ekka and Saravanan, S. S. 2020. Effect of Different Organic Manures on Plant Growth, and Establishment of Apple Guava. Int.J.Curr.Microbiol.App.Sci. 9(11): 463-466. doi: https://doi.org/10.20546/ijcmas.2020.911.057 